\title{
PREWINTERING AQUATIC AND SEMIAQUATIC TRUE BUGS IN THE TIMIŞ RIVER VALLEY: ADAPTATIONS, DIVERSITY, COMMUNITY STRUCTURE AND THE ROLE OF ANTROPIC IMPACT
}

\author{
Horea OLOSUTEAN * and Daniela ILIE **
}

\begin{abstract}
* "Lucian Blaga" University of Sibiu, Faculty of Sciences, Department of Ecology and Environment Protection and Physics, Dr. Ion Raţiu Street, 5-7 Sibiu County, Romania, RO-550012, mesaje.facultate@yahoo.com

** "Lucian Blaga" University of Sibiu, Faculty of Sciences, Department of Ecology and Environment Protection and Physics, Dr. Ion Raţiu Street, 5-7 Sibiu County, Romania, RO-550012, iliedf@yahoo.com
\end{abstract}

DOI: $10.2478 /$ trser-2013-0036

KEYWORDS: Aquatic bugs, semiaquatic bugs, Timiş River basin, habitat characteristics, anthropic impact.

\begin{abstract}
In November 2011 during a normal overwintering period, a small number of active, aquatic and semiaquatic adult insects were collected from several habitats along the Timiş River basin. This active state for the insects was closely related to higher temperatures found in certain deeper, stagnant water habitats, which also had greater amounts of aquatic vegetation and more stable living conditions. Most such habitats seem to be of anthropic origin, emphasizing the role of human impacts on the life of the discussed group of insects and the need to consider anthropic activities in the conservation of certain species of insects. The state of Aphelocheirus aestivalis is also discussed, along with a proposal to study the species on a larger scale and its possible inclusion on the Romanian Red List.
\end{abstract}

ZUSAMMENFASSUNG: Aquatische und semiaquatische Heteropteren zur beginnenden Winterzeit im Timiș-Tal (Rumänien): Anpassungen, Vielfalt, Struktur ihrer Zönosen und Rolle des menschlichen Einflusses.

Im November 2011 wurde in mehreren Lebensräumen des Timiş-Tales eine geringe Anzahl von Adulten aquatischen und halbaquatischen Heteropteren während deren Überwinterungsphase gesammelt. Ihr aktiver Zustand hängt mit Habitaten tieferer, stehender Gewässer zusammen, in denen eine höhere Abundanz an Gewässervegetation zu verzeichnen ist und stabilere Lebensbedingungen vorherrschen. Der Großteil dieser Habitate ist wohl menschlichen Ursprungs, so dass es möglich war, sowohl den Einfluss des Menschen auf die Arten der untersuchten Gruppe hervorzuheben, als auch seine Rolle für den potentiellen Schutz bestimmter Arten zu erfassen und zu bewerten. Die Situation von Aphelocheirus aestivalis wird ebenfalls dargestellt, wobei die Erhebungen $\mathrm{zu}$ der Art in größerem Umfang vorgeschlagen werden und ihre mögliche Aufnahme in die Rote Liste besprochen wird.

REZUMAT: Heteroptere acvatice și semiacvatice, în pragul iernii, în Valea Timişului (România): adaptări, diversitate și rolul impactului antropic.

Un număr mic de adulți de heteroptere acvatice și semiacvatice a fost colectat din mai multe habitate de pe Valea Timișului, în noiembrie 2011, în perioada de iernare. Starea lor activă este în relație cu habitate mai adânci și cu apă stagnantă, care au cantităţi mai mari de 
vegetație și condiții de viață mai stabile. Majoritatea acestor habitate par să fie de origine antropică, evidențiind rolul impactului antropic în distribuția grupului în discuție, dar și rolul său în potențiala conservare a anumitor specii. Situația speciei Aphelocheirus aestivalis este, de asemenea, discutată, propunându-se investigarea specie la o scară mai mare și o posibilă includere în Lista Roșie.

\section{INTRODUCTION}

Aquatic and semiaquatic bugs are a polyphyletic group of insects found throughout the globe where water and moisture are present (Andersen, 1982; Jansson, 1986; Damgaard, 2012). Their diversity is consistently higher in the southern hemisphere and in tropical regions (Froeschner, 1981; Andersen, 1982; Aukema and Rieger, 1995; Schuh and Slater, 1995), however, European species have larger ecological valences and wider distributions (Aukema, 2004). For example, insects of a particular species can be found from southern Spain to the proximity of the Arctic Circle, and from sea shores to high altitude mountain lakes and springs (Poisson, 1957; Vepsäläinen, 1974; Ilie, 2009; Olosutean and Ilie, 2010, 2013).

These types of insects have a preference for small ponds, lake shores and rivers (habitats usually covered by ice or frozen solid in the cold season), which forces them to overwinter in the mud or vegetation either at the bottom of the water body where they live or just on the shores of their habitats (Poisson, 1957; Andersen, 1982; Jansson, 1986). Field observations from the authors and from other scientists (Berchi, pers. comm.), however, showed that a small number of adults were still active throughout the winter season, especially aquatic bugs (Velia sp., Plea sp., Notonecta sp., Hesperocorixa sp. or Micronecta sp.). These insects were observed under thin ice from November to February, a time typically known as the overwintering period.

Information about the ecology of this small group seems to be incomplete. The conditions that cause some individuals to remain in an active state during winter is an important piece of the puzzle, and a first step in determining if physiological aspects are also involved in this particular adaptation. Also, it is important to find out if anthropic influences play a part in providing suitable habitats for the active overwintering of insects, which is an important aspect in possible conservation measures regarding some species of the group.

\section{MATERIAL AND METHODS Sampling}

Biological material was sampled on a single campaign in November 2011 from eleven sampling sites along the entire Timiş River valley (Fig. 1). Sites were coded TM1 to TM11, from the river's source springs to its exit from the Romanian territory.

Insects were evenly sampled in a standardized 45-minute period at each habitat, with as much heterogeneity as possible (for example, vegetation-abundant areas and open-water areas, shaded and sunny areas, deep and shallow waters, and all types of substratum). Specimens were collected using an entomological net with an $800 \mathrm{~cm}^{2}$ opening and $1 \mathrm{~mm}$ mesh, then preserved in 70\% ethylic alcohol before their identification using keys from Poisson (1957), Andersen (1993) and Davideanu (1999). A 65x Krüss MSZ5600 stereobinocular was used to identify specimens based on morphological features or, in some cases, by the structure of the genitalia. Species and higher taxa nomenclatures are presented according to Fauna Europaea (Aukema, 2004). 


\section{Data analysis}

Diversity index values were used in the analysis of the sampled species, namely Species Richness (Hill, 1973), and community heterogeneity, expressed by the inversed values of Simpson's Heterogeneity Index (Simpson, 1949).

Principal Components Analysis (PCA - Pearson, 1901) was conducted in order to point out the relations between the diversity indices and those characteristics of the sampling sites that can be extracted as continuous variables. Such characteristics were water temperature (measured with a Hanna HI 98130 tester), station size, average and maximum depth of the water (all three measured with a tape measure), and shade and vegetation coverage, both expressed as percentages (estimated from photographic material). Prior to the PCA, Pearson Product-Movement Correlation analysis was conducted on the environmental variables.

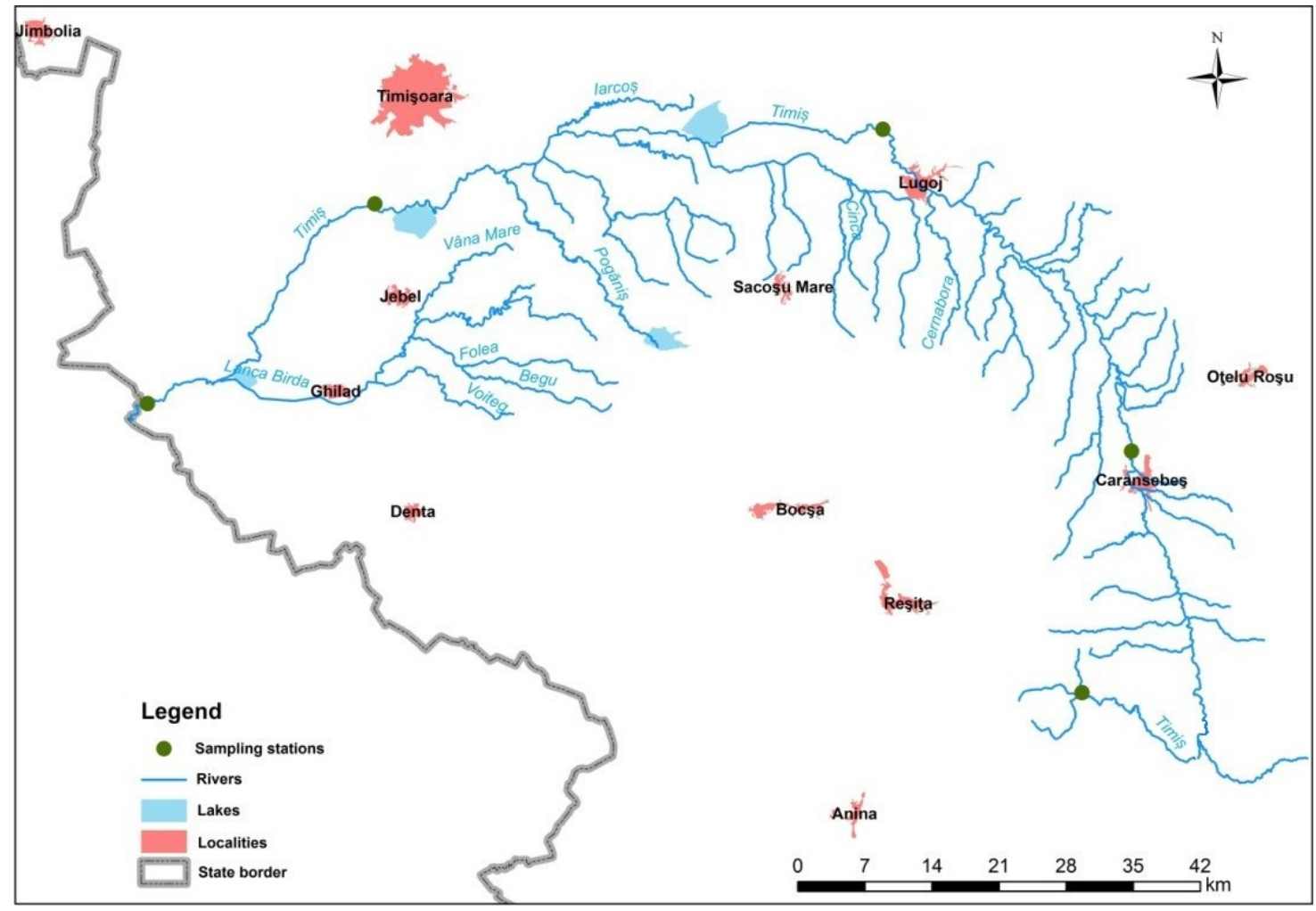

Figure 1: Location of the sampling sites on the Timiș River basin.

Simple logistic regression (LR - Agreşti, 1990) $\left(y=\exp \left(a+b^{*} x\right) / 1+\exp \left(a+b^{*} x\right)\right)$ was also used to compare diversity index values with presence-absence variables, such as the presence of aquatic and semiaquatic vegetation, water flow or the anthropic genesis of the sampling sites. Both PCA and LR were conducted in STATISTICA v. 10 (StatSoft, 2010).

$$
\sum_{i=1}^{R} p i * \log p i \ln S
$$




\section{RESULTS AND DISCUSSION}

Only nine species of Heteroptera (eight aquatic species and one semiaquatic species) were collected from six of the eleven sampling sites (Tab. 1). Considering there are 70 species of Heteroptera already found in Romania (Davideanu, 1999; Ilie, 2009; Berchi, 2011, 2012), this number is very low for such a large area but can be explained by the weather conditions during the sampling season.

Table 1: List and presence of aquatic Heteroptera species from the Timiș River valley and the values of diversity indices.

\begin{tabular}{|l|c|c|c|c|c|c|}
\hline \multicolumn{1}{|r|}{ Sampling site } & TM2 & TM4 & TM5 & TM9 & TM10 & TM11 \\
\hline $\begin{array}{l}\text { Taxa } \\
1758\end{array}$ & $\star$ & & $\star$ & $\star$ & & $\star$ \\
\hline $\begin{array}{l}\text { Notonecta (Notonecta) viridis Delcourt } \\
1909\end{array}$ & & & & & & $\star$ \\
\hline Corixa affinis Leach 1817 & & & & & & $\star$ \\
\hline Sigara (Sigara) striata (Linnaeus 1758) & & & $\star$ & & & $\star$ \\
\hline $\begin{array}{l}\text { Sigara (Vermicorixa) lateralis (Leach } \\
1817 \text { ) }\end{array}$ & & & & $\star$ & & \\
\hline Subsigara sp. Stichel 1935 & & $\star$ & & & & \\
\hline $\begin{array}{l}\text { Ranatra (Ranatra) linearis (Linnaeus } \\
\text { 1758) }\end{array}$ & & & $\star$ & & & \\
\hline $\begin{array}{l}\text { Aphelocheirus (Aphelocheirus) aestivalis } \\
\text { (Fabricius 1794) }\end{array}$ & & & & & $\star$ & \\
\hline Gerris (Gerris) lacustris (Linnaeus 1758) & $\star$ & & & & & \\
\hline Species Richness & 2 & 1 & 3 & 2 & 1 & 4 \\
\hline Heterogeneity & 0.667 & 0 & 0.8 & 1 & 0 & 0.768 \\
\hline
\end{tabular}

The number of individuals was also very low. Only 20 adults and one larva were collected. Since almost all species spend winter as adults, the presence of larvae was unusual as the insect community is mainly made up of adults during this time. The low number of individuals is also normal since the large majority of the Heteroptera are already hidden in mud or moist vegetation in preparation for the winter season. The larva we sampled belonged to A. aestivalis, which has a unique biological cycle among the Heteroptera and is found as both larvae and adults throughout the cold period (Papáček, 2001; Papáček and Soldán, 2008).

As expected, species richness values were very low, but the heterogeneity of the community was surprisingly high in four of the six stations where Heteroptera were found. Because no more than three individuals from the same species were collected at any given site, the communities are apparently equilibrated, hence the higher heterogeneity. 
We would expect to see temperature variations between the average depth and the maximum depth at sampling sites $\left(\mathrm{r}^{2}=0.81, \mathrm{p} \leq 0.01\right)$. The presumption that the relationship between higher water temperatures and increased vegetation $\left(r^{2}=0.81, p \leq 0.01\right)$ is easily explained by the fact that warmer water allows for greater concentrations of vegetation during the colder periods of the year. However, the close correlation between the maximum depth of sampling sites and the abundance of aquatic vegetation was surprising $\left(r^{2}=0.71, p \leq 0.02\right)$. A probable explanation for this is the relative consistency of the water temperature in deeper stations, which may be preferred by aquatic plant species.

Almost three quarters of the variation of environmental variables $(74.35 \%)$ was explained by the first two axes of the PCA (Tab. 2). The first factor is strongly correlated with temperature, average and maximum water depth, vegetation, and shading. The second axis is related to station size and, to a lesser extent, average water depth. Biodiversity values are related to the first factor; therefore station size should be not as important as the rest of the environmental variables.

Table 2: Correlation between environmental variables/diversity values and the first two PCA factors.

\begin{tabular}{|c|c|c|}
\hline PCA Factor & Factor 1 & Factor 2 \\
\hline Environmental variable/diversity & $(51.1 \%)$ & $(23.25 \%)$ \\
\hline Temperature & -0.833325 & 0.308627 \\
\hline Size & -0.136204 & 0.849203 \\
\hline Average water depth & -0.729873 & -0.558915 \\
\hline Maximum water depth & -0.867263 & -0.313141 \\
\hline Vegetation coverage percentage & -0.884114 & 0.107283 \\
\hline Shading percentage & 0.535217 & -0.395747 \\
\hline Species Richness & -0.817729 & 0.113962 \\
\hline Heterogeneity & -0.765490 & 0.241066 \\
\hline
\end{tabular}

PCA analysis (Fig. 2) confirmed the correlations that higher values of both species richness and heterogeneity are related to higher temperatures and greater amounts of vegetation. Deeper water depth also positively influences the values of biodiversity, but that influence is not as strong as influences from vegetation or temperature. On the other hand, a higher shading percentage has a negative influence on species diversity, while the size of the station is not important for the group's distribution based on the sampling sites.

In other words, aquatic and semiaquatic bugs prefer deeper, highly-vegetated habitats where water temperatures are warmer than the neighboring water bodies. These insects avoid shaded areas most likely because sunny habitats heat up more quickly during the small period of daily sun exposure during the winter months. Temperature seems to be the most important factor in this equation and it influences all the other variables: deeper stations have a more stable temperature throughout the year, higher amounts of vegetation provides shelter and also regulates the habitat temperature, while shade inhibits temperature increases. From this point of view, the size of the station is not important because station size does not influence the temperature of the water. Two habitats of the same size but with different water temperatures and vegetation amounts would have completely different diversity values. 
Logistic regressions showed that anthropic constructed habitats revealed greater species richness $(p \leq 0.01)$ and higher heterogeneity $(p \leq 0.1)$, while the presence of vegetation was a determinant for higher values of diversity indicators $(\mathrm{p} \leq 0.005$ for both species richness and heterogeneity). A comparison between lentic and lotic habitats indicated that stagnant waters fostered more species richness $(\mathrm{p} \leq 0.05)$, although a relation between water flow and heterogeneity is not significant.

As a general conclusion, warmer habitats demonstrate a higher probability of hosting active, individual aquatic or semiaquatic bugs. Such habitats are mostly small ponds or swampy pools from the river meadows, created by water accumulations in human-made excavations or embankment-related construction. Slow-moving or still water allows for increased vegetation coverage and organic loadings in the water, which leads to higher water temperatures, making these sites the most suitable habitats for active, pre-wintering adults. In all situations, only a small number of individuals are still active in colder waters, the large majority of the populations having already prepared for winter. A consistent explanation for the activity of insects during the cold season is still under study.

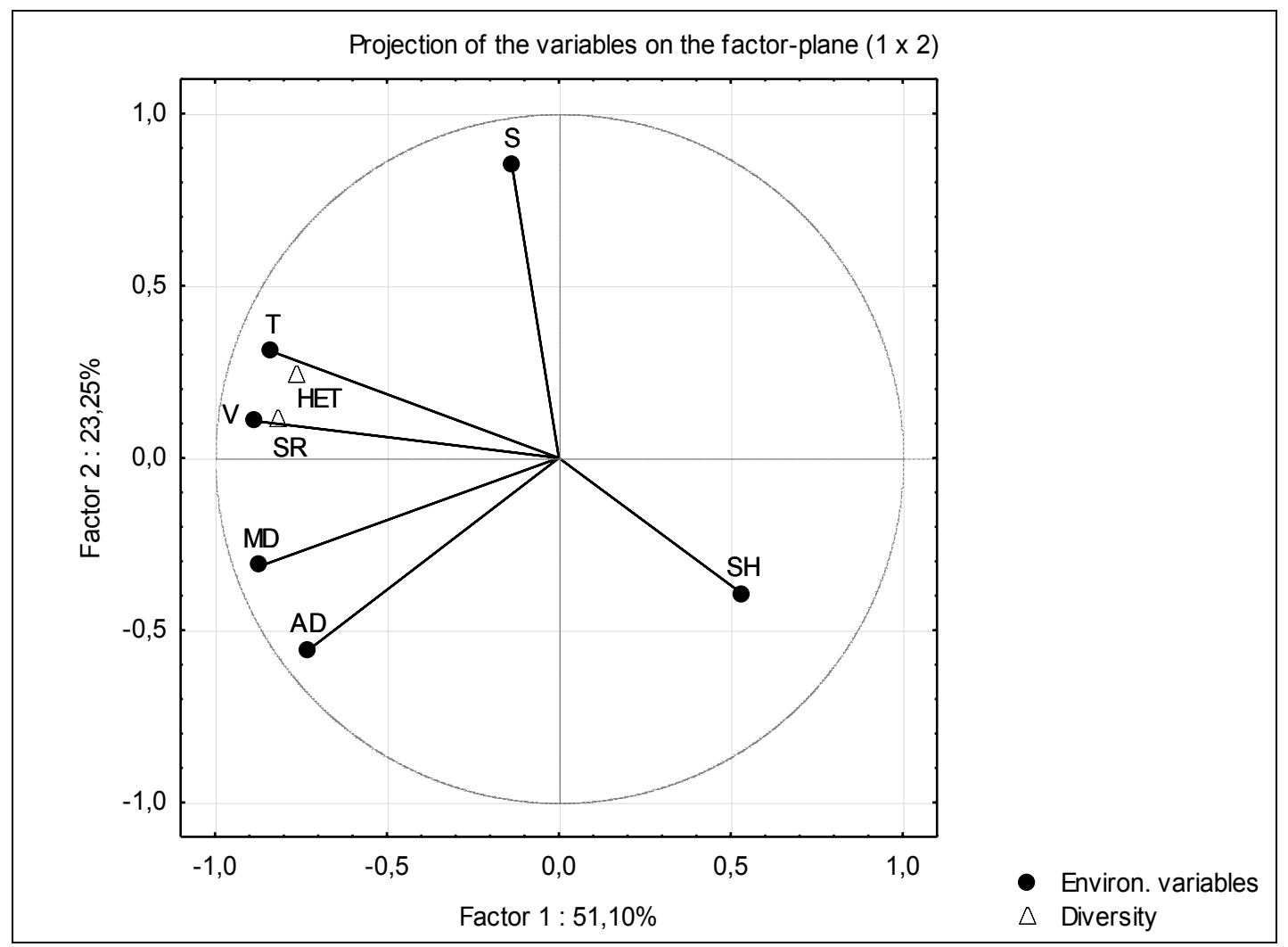

Figure 2: PCA biplot of biodiversity and environmental variables (T - temperature, $\mathrm{V}$ vegetation coverage, $\mathrm{MD}$ - maximum water depth, $\mathrm{AD}$ - average water depth, $\mathrm{S}$ - habitat size, SH - shading percentage, SR - Species Richness, HET - Heterogeneity). 
A special discussion should be raised about A. aestivalis, a particular member of the group and the only benthic Heteroptera. This species is red listed in some European countries and declining in some areas (Damgaard, 2005). Papáček and Bauer (2006) consider $A$. aestivalis as sensitive to habitat destruction more so than to pollution or other physicochemical alterations of the water.

The species was found in only one of the 24 benthic samples taken from the Timiş Valley (Bănăduc A., pers. comm.). The Timiș Valley has been strongly affected by the extraction of construction materials (gravel pits are present throughout most of the middle and lower parts of the Romanian section), which frequently change the hydrological conditions (substratum granulation, dissolved oxygen quantity, etc.). A. aestivalis strongly prefers a sandy or rocky substratum, high water speed and sufficient oxygen, and the ever-changing conditions along most of Timiss Rivers' course could be the cause for the insect's migration towards the Romanian-Serbian border.

In fact, the Romanian distribution of A. aestivalis is highly unknown and it is possible this population is being further reduced by the increase in industrial activities from the river valleys and meadows due to micro-hydro plants, gravel pits, and tourist facilities, etc. This hypothesis could open a discussion for a more comprehensive study of the species and possible inclusion on the Red List of Romanian Fauna.

\section{ACKNOWLEDGEMENTS}

This study was funded by "Study of the quality of Timiş water and registry of polluters source to border" (IV.1.2), a Phare CBS contract, no. 411 - 90964/30.12.2010/07 of "Lucian Blaga" University, Faculty of Sciences, financed by the European Community. Special thanks to Mrs. Bănăduc A. and Mr. Bănăduc D. for the logistic support and for benthic invertebrates information. 


\section{REFERENCES}

1. Agreşti A., 1990 - Categorical data analysis, John Willey and Sons, New York, 573.

2. Andersen N. M., 1982 - The semiaquatic bugs (Hemiptera, Gerromorpha) phylogeny, adaptations, biogeography and classification, Scandinavian Science Press Ltd., 445.

3. Andersen N. M., 1993 - Classification, phylogeny, and zoogeography of the pond skater genus Gerris Fabricius (Hemiptera: Gerridae), Canadian Journal of Zoology, 71, 12, 2473-2508.

4. Aukema B., 2004 - Fauna Europaea: Heteroptera - Nepomorpha, Fauna Europaea version 2.5, http://www.faunaeur.org.

5. Berchi G. M., 2011 - First record of Anisops sardeus (Hemiptera: Heteroptera: Notonectidae) in Romania, North-Western Journal of Zoology, 7, 2, 339-341.

6. Berchi G. M., 2012 - First record of the backswimmer Notonecta maculata in Romania, Travaux du Muséum National d'Histoire Naturelle "Grigore Antipa”, 55, 2, 217-220.

7. Damgaard J., 2005 - Distribution, phenology and conservation status of three rare water bugs: Aquarius najas (De Geer, 1773), Aphelocheirus aestivalis (Fabricius, 1794) and Sigara hellensi (C. R. Sahlberg, 1819) from lotic waters in Denmark (Insecta, Hemiptera-Heteroptera: Nepomorpha and Gerromorpha), Entomologiske Meddelelser, 73, 25-38.

8. Damgaard J., 2012 - What do we know about the phylogeny of the semi-aquatic bugs (Hemiptera: Heteroptera: Gerromorpha)? Entomologica Americana, 118, 1, 81-98.

9. Davideanu A., 1999 - Contribuţii la studiul heteropterelor acvatice din România, Ph.D. thesis, Babeș-Bolyai Univesity, Cluj-Napoca.

10. Froeschner R. C., 1981 - Heteroptera of true bugs from Ecuador: a partial catalogue, Smithsonian Contribution to Zoology, 322, 1-258.

11. Hill M. O., 1973 - Diversity and evenness: a unifying notation and its consequences, Ecology, 54, 427-432.

12. Ilie D. M., 2009 - Heteropterele acvatice şi semiacvatice (Heteroptera: Nepomorpha, Gerromorpha) din bazinul mijlociu al Oltului, Edit. Altip, Alba Iulia, 279. (in Romanian)

13. Ilie D. M. and Olosutean H., 2009 - Aquatic and semiaquatic Heteroptera from Arieş River Basin: methods in estimating biodiversity, Transylvanian Review of Systematical and Ecological Research, 7, 77-86.

14. Olosutean H., Olosutean C. and Ilie D. M., 2013 - High morphological variability of Gerris argentatus Schumel 1832 (Heteroptera: Gerridae) and probably Europe's smallest gerrids, in the Danube Delta, Transylvanian Review of Systematical and Ecological Research, 15, 2, 111-116.

15. Jansson A., 1986 - The Corixidae (Heteroptera) of Europe and some adjacent regions, Acta entomologica fennica, 47, 1-94.

16. Papáček M., 2001 - Small aquatic and ripiculous bugs (Heteroptera: Nepomorpha) as predators and prey: the question of economic importance, European Journal of Entomology, 98, 1-12.

17. Papáček M. and Bauer M., 2006 - Benthic water bug (Aphelocheirus aestivalis) (Heteroptera: Aphelocheiridae) in the upper Lužnice River basin (Czech-Austrian border area), Beitrage zur Entomofaunistik, 7, 193-195.

18. Papáček M. and Soldán T., 2008 - Structure and development of the reproductive system in Aphelocheirus aestivalis (Hemiptera: Heteroptera: Nepomorpha: Aphelocheiridae), Acta Entomologica Musei Nationalis Pragae, 48, 2, 299-318.

19. Poisson R., 1957 - Faune de France 61: Hétéroptères Aquatiques, Librairie de la Faculte des Sciences, Paris, 301. (in French)

20. Savage A. A., 1989 - Adults of the British aquatic Hemiptera Heteroptera - A key with ecological notes, Freshwater Biological Association, Ambleside, 173.

21. Simpson E. H., 1949 - Measurement of diversity, Nature 163, 688-688.

22. StatSoft, Inc., 2010 - Electronic Statistics Textbook, Oklahoma, www.statsoft.com/textbook

23. Vepsäläinen K., 1974 - The life cycles and wing lenght of Finnish Gerris Fabr. species (Heteroptera, Gerridae), Acta Zoologica Fennica, 141, 1-73. 